Article

\title{
Framework for Decision-Making Process in Granting Rights to Use Hydropower in the European Context
}

\author{
Guillaume Voegeli ${ }^{1,2, *(D)}$, Ludovic Gaudard ${ }^{3}$, Franco Romerio ${ }^{1}$ and Werner Hediger ${ }^{2}$ \\ 1 Energy Economics and Policy Research Group, Institute for Environmental Sciences, University of Geneva, \\ Geneva 1205, Switzerland; Franco.romerio@unige.ch \\ 2 Center for Economic Policy Research, University of Applied Sciences HTW Chur, Chur 7000, Switzerland; \\ Werner.hediger@htwchur.ch \\ 3 Precourt Energy Efficiency Center, Management Science and Engineering, Stanford University, Palo Alto, \\ CA 94305, USA; Gaudard@stanford.edu \\ * Correspondence: Guillaume.voegeli@etu.unige.ch; Tel.: +41-22-379-0797
}

Received: 29 May 2018; Accepted: 10 July 2018; Published: 13 July 2018

\begin{abstract}
The European electricity landscape is facing an ambivalent situation between: (1) common market platforms; and (2) national and subnational jurisdictions, which impose their specific rules on energy sectors. This particularly affects hydropower, as the latter faces inequalities in the procedures needed for the attribution of water rights. Besides jurisdictional disparities, the European Union requires this attribution to follow competitive processes and the integration of sustainable development goals for energy projects, while other countries connected to the European grid such as Switzerland and Norway still know different procedures and requirements. Therefore, this article addresses concerns regarding the lack of harmonization of water regimes in Europe. Imposing a common jurisdiction to countries connected to the European grid would be politically very challenging. Our approach overcomes this challenge by proposing a process adaptable to specific local rules and allows a comparison of water rights attribution procedures. In this frame, we propose a nine-step process, based on three goals: (1) to enhance competitive access by ensuring the highest rent transfer related to water rights; (2) to prioritize projects closer to sustainability goals; and (3) to ensure the efficiency of the process itself.
\end{abstract}

Keywords: hydropower; water rights; Europe; decision support; sustainability; rent transfer

\section{Introduction}

Hydropower has been present since the early days of electricity production and represents the largest share of renewable power generation worldwide [1]. With nearly one quarter of the world total production, the European region represents the second largest hydropower producer, after East Asia [2]. Obviously, national hydropower production largely varies between European countries, but can represent more than one half of the national production, such as in Norway, Austria and Switzerland [3]. Moreover, the new European goals, by promoting a higher share of renewable in the power sector, could induce further development of the current installed capacity [4]. Besides, Europe has experienced a wave of liberalization [5] since the early 1990's, when Britain and Norway opened their electricity market to competition [6,7], along with an increasing integration of the continental grid [8]. As a result, actors in the power market sector (i.e., power producers and buyers) are now allowed and able to exchange electricity through free-trade markets, which are run following a common set of rules [9]. This common market largely contrasts with the vast diversity of national and subnational regulations the hydropower sector has to confront and undoubtedly creates market distortions for the latter [10]. 
Indeed, due to its very nature, hydropower is intimately linked to water rights. The latter refer to the legal access to exploit a watercourse and their diversity is large at the international level [11]. Glachant et al. [10] conducted an extensive review of those water rights across 10 European countries and found a considerable pluralism between jurisdictions. The granting authorities are either at the national (e.g., Norway), regional (e.g., Sweden) or municipal level (e.g., within some Swiss cantons), while the water rights granted can be unlimited (e.g., Sweden, Great Britain for rights granted before 2003) or limited in time, from 90 years (Austria) down to a maximum of 30 years (e.g., Germany and Italy). The obligations imposed to the hydropower operations are also different between jurisdictions. Regarding environmental obligations, some of them are forced to provide an environmental impact assessment (e.g., in Norway, Spain), must release a residual water flow during operation (e.g., France, Switzerland) or even both (e.g., Austria, Great Britain). The definition of small and large hydropower facilities, based on the installed capacity, also varies from less than $1 \mathrm{MW}$ (Germany) to less than $10 \mathrm{MW}$ (e.g., Portugal). The granted rights and the obligations imposed to the hydropower operators may then differ based on this criterion [10].

Another type of obligation concerns the hydropower royalties, serving as a redistribution mechanism for resulting benefits. An adequate distribution of those benefits is one of the conditions for sustainable implementation of hydropower [12]. Up to date, only little has been written on international comparison of those pecuniary obligations and on criteria that should be considered in that regard [13]. A major contribution for the European context is a further study conducted by Glachant et al. [14], in which they argue for harmonization of hydropower regimes to mitigate competition distortion. However, the implementation of a common hydropower regime in Europe could prove to be very challenging. Instead, we suggest a common process to attribute water rights to generate hydroelectricity, which could overtake jurisdictional specificities.

Although built for European Union members, the European Commission already provides an attribution process framework through the Directive 2014/25/EU. However, this directive only indirectly addresses the specific aspects of hydropower. This article aims therefore to bridge the gap between this European Directive and the attribution of water rights to use hydropower (the granting of water rights to one entity by another).

The final goal is twofold. First, we propose a non-discriminatory and harmonized access to the water right market, which consequently should prevent electricity market distortions caused by contract-based barriers to entry. Second, the attribution process should prioritize those projects that are the closest to the United Nations Sustainable Development Goals (SDGs). In fact, the application of article 11 of the Treaty on the Functioning of the European Union (TFEU) requires applying SDGs in European policy, as underlined in the rec. 96 of the Directive 2014/25/EU. Therefore, we propose a competitive process to select a hydropower project that, following rec. 83 , is in line with a predefined set of sustainable development goals and, according to rec. 26 and 95 of the Directive 2014/25/EU, limits distortions in the attribution.

\section{Fundamental Concepts}

\subsection{The Water Resource Rent}

Any hydropower plant benefits from water availability by exploiting the "bounty of nature" [15]. It provides a resource rent that, in turn, represents an additional income to the holder of the resource rights. Formally, a rent is defined as a return rate above the rate required for keeping the factor in use, exceeding the normal profit that would theoretically be realized in a perfectly competitive market. Rothman identifies two components of the hydropower rent and reasons for its existence [16]:

1. Scarcity rent: The limited supply of a natural resource constrains production below the quantities demanded and allows producers to set the price higher than the marginal cost. Hence, the market will be balanced by a rationing price, and the profit exceeds the normal one. 
2. Differential rent: Due to differences in the production costs ensuing from the heterogeneity of the natural resources used by different companies at different locations, some firms can take advantage of an additional profit.

The water resource rent resulting from hydropower corresponds to the difference between the price of electricity and the unit costs of turning the water resource into electricity. It is the surplus that could be distributed among profit, taxes and income to the holder of the property rights. The latter may be willing to transfer the water rights, or at least some attributes thereof, to another entity. The principal-agent theory [17] provides a relevant framework to characterize the asymmetry of information existing between the holder of property rights and the entity willing to exploit the resource. In the specific case of hydropower concessions, the conceding authority defined by the jurisdiction is the principal (e.g., national entity, federated state, municipality) while the agent is usually an electricity producer (e.g., private or public power company) having the skills to economically exploit the water resource. The agent should thereafter share the benefit of exploiting the resource with the principal by means of a transfer mechanism. Called water fees, this transfer mechanism could be either a tax (profit-related), a royalty (related to the resource and not the profit) or a mix of both [16] and can either be charged periodically or at the beginning of the project. The specific asymmetry between the principal and the agent in the context of hydropower will be detailed in the Section 3.1 of this article. Besides, further details can be found in the environmental economics literature about the most efficient rent transfer mechanism [18-20].

\subsection{Sustainability}

Sustainable development (SD) is a normative principle guiding policy, which has increasingly been used by decision makers worldwide in recent decades [21,22]. It refers to a process of change that confines social and economic development [23] and that involves consideration of various concerns across the economic, societal and environmental domains [24,25]. Accordingly, the terms of sustainability are not static. Preferably, they are "a response to evidence that current conditions and trends are not viable in the long run, and that the reasons for this are as much social and economic as they are biophysical or ecological" [26].

Currently, SD is a key guiding principle for policy and business development across the planet $[27,28]$. Ensuing from this increasing need for SD policies and strategies, sustainability assessment (SA) is emerging as a fundamental decision support tool [29]. It can provide decision makers with relevant information and analysis [30]. However, there is no consensus about the definition and methodology of SA. Rather, numerous methods exist, ranging from indicator-based and product-related tools, to integrated assessment approaches [31]. Thus, a methodological choice has to be made and applied within the process of granting water rights. This choice will depend on the background of the analyst and the people involved. In any case, SA should ensure to provide "an evaluation of global to local integrated nature-society systems in short and long-term perspectives in order to assist [the decision makers] to determine which actions should or should not be taken in an attempt to make society sustainable" [31], based on [32].

If new energy projects must be sustainable [33] then SA should precede any decision regarding the implementation or retrofitting of any power plant. It requires a comprehensive project-related assessment. The impacts on the three domains, that is, the economy, society and the environment, must be evaluated, such as to include the external costs and benefits in the overall rent assessment. This is even more fundamental in the specific case of hydropower, with its large and long-lasting infrastructure [34] and the potential impacts of hydropower electricity generation [35-38]. Those impacts range from local to global scale, from direct environmental impacts on the hydropower site and downstream ecosystems [39] to displacement of people and resettlement [40], to the degradation of and questioning the economic relevancy of those infrastructure [41]. 


\section{General Framework}

\subsection{Hypothesis and Goals of the Process}

In line with earlier work on bidding processes [42-44], we propose an approach for granting hydropower rights that shall be open to competition. Glachant et al. [14] underline this requirement in the specific context of European hydropower, which is considered in the European Directive 2014/25/EU (rec. 20, 61).

In a perfectly competitive market, and in the case of a one-dimensional financial bid, the attribution process would not represent a challenge, as the market would lead to an efficient choice. Indeed, the principal would grant the water rights to the agent that offers the highest transfer of rent. The competition between agents would create a strong incentive to reduce the costs and optimise the project design to come up with the best possible financial bid and the entire capture of the rent. In practice, however, one cannot assume perfect competition, as only a limited number of companies submit a project. This is especially true for the hydropower sector, where various barriers to entry limit competition. Indeed, the high capital intensity of hydropower projects and the specific skills required to operate them represent, among other aspects, a cost disadvantage independent of the size barrier, as defined by Porter [45].

Also, a decision can hardly be taken based only on one simple criterion (e.g., financial values). Bids must therefore be multidimensional and other attributes should be considered, whereas some criteria can be qualitative (art. 82 of Directive 2014/25/EU). Beside socio-economic and environmental aspects, the quality of the project or of the agent should also be evaluated. Therefore, the principal has discretion in the final choice, thus facilitating discrimination [45].

The principal also suffers from three constraints: informational, transactional, and administrative \& political [46]. The informational constraint refers to moral hazard and adverse selection issues. In the electricity sector, the agent usually possesses better information than the principal [47], which can be used strategically [48]. The transactional constraint is embodied by the important costs related to the writing and enforcing of a contract [49] or to the organisation of a bid [44]. Those large costs generally result in an incomplete contract, as the latter cannot include every contingency [50,51], which can be strategically used by both sides. Finally, the administrative and political constraint designates the limits imposed by the implied jurisdiction, such as the enabled transfer mechanism. Moreover, administrative processes specific to the jurisdiction may also be an increasing cost factor.

This asymmetrical relation between both parties raises issues, which should be prevented, or at least limited. In that regard, the process aims to help the principal to minimize the asymmetrical information. Designed in a stepwise procedure, it enables an incremental collection of information from the agents and the reduction of complexity in each step. It also allows the gradual elimination of project options that do not fulfil the respective requirements after each step. While they are worth being mentioned, issues related to both the transfer mechanisms and the effective contracting and implementation are strictly linked to the concerned jurisdiction, and their analysis is not treated in this article.

Despite multidimensionality and deviation from perfect competition, the granting process must achieve three goals. First, non-discrimination should be ensured, and strategic behaviour and collusion be avoided, as underlined by Laffont and Tirole [46] and specified in rec. 19, 26 and 95 of the Directive 2014/25/EU. The same applies to political, regional and other preferences. It goes with the idea to prevent distortion of the electricity market. Second, the bidding process itself should minimize the transaction cost of the bidding [44]. In particular, it should be kept as simple as possible. For this purpose, we put the costliest steps, regarding information gathering, to the end of the process, when only the most promising projects remain on the table. Such simplification can also mitigate discrimination [46]. Third, to be granted the project must undoubtedly contribute to the goals of sustainable development, which is in line with the article 11 of TFEU, mentioned in the rec. 96 of the Directive 2014/25/EU. 


\subsection{Detailed Process Steps for Granting Hydropower Water Rights}

The process can be indifferent to a new project or the renewal of ongoing water rights. Although an agent can present an initiative for a new project, it is ultimately the principal who is in charge of launching the competitive granting process. The latter is divided in a total of nine steps, as shown in Figure 1, which would ideally be coordinated with a stakeholder process. Each step of this procedure is detailed in the following subsections, where the entity in charge of each step is indicated in parentheses.

Step 1: Gathering of essential necessary information (Principal)

In this first step, according to the scientific literature, two essential pieces of information need to be gathered:

(1) The spatial limits of the project must be defined. This gives preliminary information regarding the impacted area if the project would be implemented. The recognition of the unique situation and configuration of the concerned area sets the essential frame for any further investigation, especially regarding impact and sustainability assessment. Indeed, "the context of an individual sustainability assessment needs to be determined on a case-by-case basis as the context differs" [29].

(2) The major stakeholders must be identified, as the integration of stakeholders' perspectives in the process and methodology are required to make any SA more robust and successful [52,53]. "Stakeholder" refers to "any group or individual that can affect or be affected by the realization of an organization's purpose", which can either be an action or a decision [54]. In the case of hydropower, stakeholders can be of multiple types, such as environmental or conservation Non-Governmental Organizations (NGOs), representatives of local people and representatives of local and regional economic interests. However, inclusion criteria can be set by the principal, to define the characteristics stakeholders must share to participate (e.g., local inhabitant, interest group member, etc.). Their integration allows confirming or adapting the initial conceptual frame to the specificities of the project [55]. It facilitates the anticipation of opposition to the project and future refusal. The integration of stakeholders has already been used in energy-linked research [56,57]. However, the deficit of methods for their practical identification has been pointed out, and a snowball sampling process has been suggested to achieve this task, relying on the contacts of each involved stakeholder [58]. Making new contacts can also prove easier, as it is supported by insiders (e.g., interest group and NGOs members, local people) and can eventually increase the trust in the process by other participants [59]. This is particularly important about the SA process, for which a progressive establishment is required, as it includes time consuming procedures such as stakeholder involvement and trust acquirements. Indeed, the snowball sampling procedure has already been successfully applied in hydropower assessment projects to identify local actors [60]. The method used to integrate stakeholder mainly depend on the resources available and methodological choices. For instance, in-depth interviews [61], surveys [56] or workshops [62] have been used. 
FRAMEWORK FOR DECISION-MAKING PROCESS IN GRANTING RIGHTS TO USE HYDROPOWER IN THE EUROPEAN CONTEXT

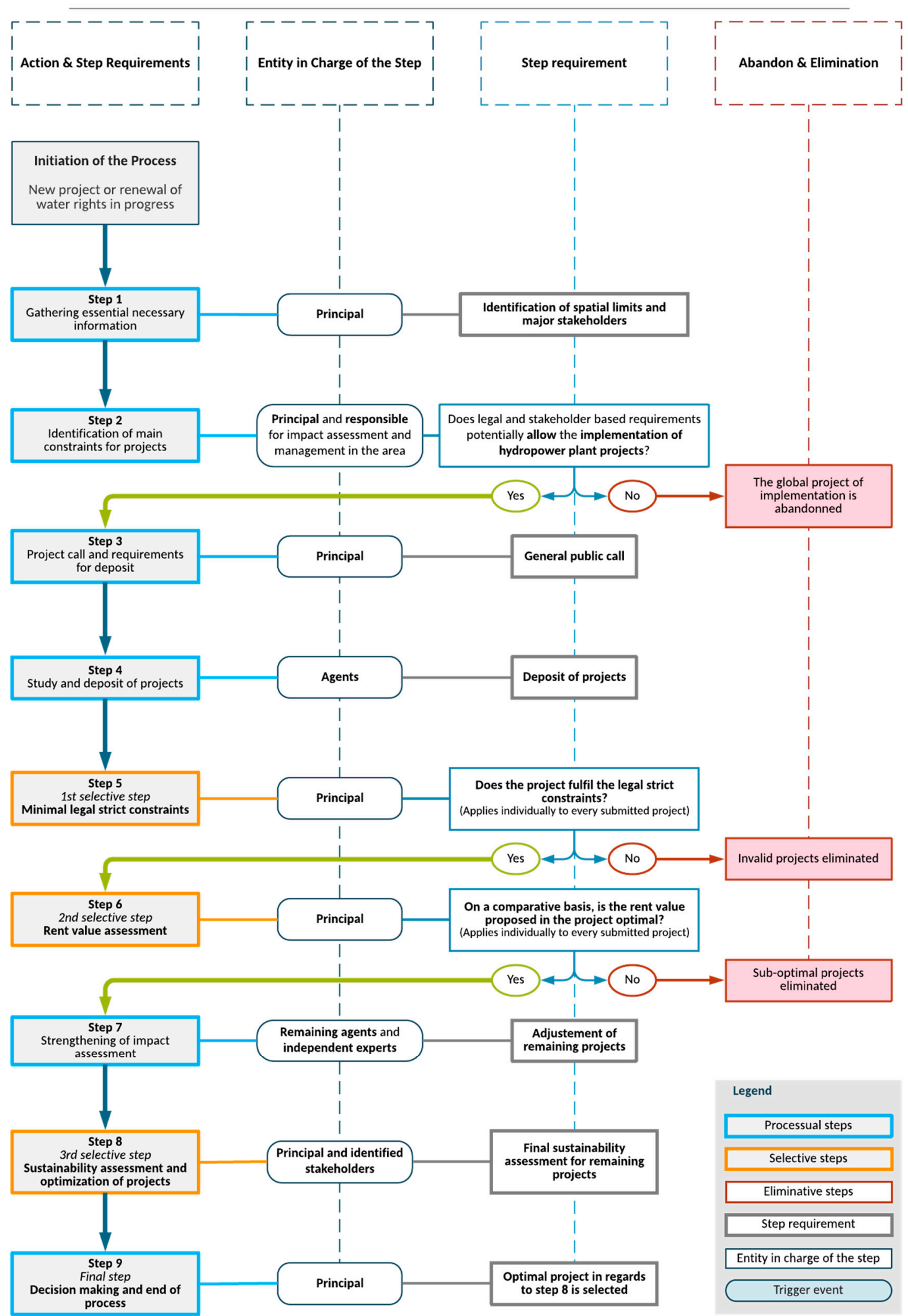

Figure 1. Framework for decision making process in granting rights to use hydropower in the European context. 
Step 2: Identification of main constraints imposed on projects and initiation of an integrated SA and stakeholder process (Principal, which can be supported by the authority responsible for impact assessment and management, e.g., environmental agency)

With the aim to identify the major site-specific constraints, this step is to evaluate the legal, social and environmental feasibility of a project at a given location. This identification of the constraints should be performed through an iterative process of technical sustainability assessment and stakeholder dialogue [63]. It involves three sequential subtasks:

(1) The principal and other authorities in charge must specify the legal feasibility of a project. For instance, some area may be of high environmental interest. It should be stated if any future projects might enter in conflict with some preservations laws. The case could be complex and an analysis performed by a legal expert may be required.

(2) A preliminary iteration process, starting with a core group of stakeholders [64] has to be put in place. At this early stage of project planning, the main stakeholders' perspectives are fundamental to identify the critical aspects and impacts. Though, the general legal frame and requirements might be known, the stakeholder process may help to early identify additional specificities and basic constraints of the site. This could also be part of a broader political process and debate [65]. Accordingly, fundamental limits must be determined, which are not subject to any trade-off and negotiations. For instance, fundamental limits can define the maximal surface covered by the reservoir or the level of the minimal water flow that must be constantly released (i.e., higher than legal constraints).

(3) Based on a first study of the potential impacts, a preliminary sustainability assessment must be conducted by "technical" experts and core stakeholders. This study must focus on the main impacts that are expected from the project as well as the critical aspects previously identified by the stakeholders. It can be supported by independent impact assessment agencies and sets the general frame of further and in-depth sustainability assessments.

By this preliminary assessment, the principal states on the legal feasibility and the environmental, social and economic acceptability of a hydropower project in the area under consideration. In case the conditions are met to carry on the process, the information gathered shall be provided to all potential agents. The Directive 2014/25/EU (127) recommends sharing information to increase the efficiency of the process. It allows the agents to modulate their proposal and anticipate latter opposition from stakeholders and interest groups. If the project is not considered as feasible, the whole process is stopped.

Step 3: Project call and requirements for deposits (Principal)

The principal announces a general public call for projects. He also explicitly sets the "rules of the game", in other words, the attribution criteria, as required in the art. 94 of the 2014/25/EU Directive. In particular, it must provide the parameters to be considered in the rent and sustainability assessment. As there is no consensus on the method of SA, it is highly recommended to specify the detailed methodology in the call. The principal should also specify the conditions for the rent transfer mechanism, if not defined by the law. Setting the "rules of the game" facilitates the comparison between projects. It also increases the efficiency of the process (Directive 2014/25/EU, rec. 127), as the agents can better meet the expectation of the principal.

At this step, it is essential to seek competitive bids. It aims to limit collusion and infringement of competition laws. It is also an opportunity for the principal to gather information coming from various sources to limit the asymmetry of information. Therefore, the principal shall encourage for multiple or flexible project deposits. For instance, the agents could suggest various power capacities. As a result, they may maximise their chance to be accepted in the following steps, while the principal may obtain information that help to better compare the projects. The expected high competition at this stage creates an incentive for agents to give accurate information.

Step 4: Elaboration and projects deposit (Agents) 
During the study phase, the agents must collect every piece of information about the costs of their project(s). In detail, applicants have to provide the costs related to initial investment and operations. If required by the principal, the applicants also have to provide the costs for the decommissioning of the installation. An estimation of the taxes and royalties legally imposed, such as water fees per theoretical power, should also be performed. Also, the agents can anticipate the final SA process by expanding the planned compensation and mitigation measures beyond minimum requirements. Those mitigation and compensation measures can be of various kinds, as they can include the initial set up (e.g., additional impact mitigation infrastructure), continuous actions (e.g., preservation of natural habitat in a specific area), limitations of impact generating operations (e.g., control of hydropeaking, minimal release of water), or long-term planning for infrastructure decommissioning. It provides options that can increase the rate of success of the project, as it may be adapted to meet the expectations of the principal.

For each option, the agent must assess the tax and royalties that the principal could expect. The assumptions to compute the level of water fees must be provided. For instance, the future price scenarios should be confidentially presented. This justifies the value of the water right given by the agent. The principal can assess whether the rent transfer is coherent with the scenarios provided. The principal can also compare the scenarios provided by the competitors. It helps to identify whether an agent tends to provide irrelevant scenarios to affect the outcome. It mitigates the risk of infringement to competition laws.

We also highly recommend the principal to ask for assessing the water fees with the historical prices. It enables them to compare the various projects design on a frequent basis. However, this information will not provide relevant information about the rent assessment. Indeed, it does not consider the evolution of price.

\section{Step 5: First selective step-Minimal strict legal constraints (Principal)}

This step aims to eliminate projects that do not fulfil the minimum requirements previously set (i.e., main constraints and legal obligations determined in step 2 and communicated in step 3). As a checking step, it ensures that all the projects respect the rules of the game. Therefore, it avoids wasting resources in the selection process for any project that could not or should not be legally selected.

Step 6: Second selective step—Rent value assessment (Principal)

The first comparison between all submitted projects takes place at this point. Aiming to avoid infringement of the competition rule, this step is purely a financial selection. Here should be discarded and rejected the sub-optimal projects, due to their underestimation of the value of the potential rent transfer compared to the other projects. This process should also give consideration to the cost or financial impact of mitigation and compensation measures.

The number of applications and options submitted may strongly vary between each granting process. Two situations may be faced:

(1) Competition dynamics can be assumed: If enough projects options are submitted, direct comparison may be performed. It is made between projects with similar technical features, such as power capacity. It is the very reason why agents are asked to provide various or flexible options in their submission. The cost of mitigation measures can be deduced from the potential rent transfer.

(2) Competition is low: If only a few options are submitted, the selection must be adjusted. Of course, this situation is less desirable for the principal. He may have to conduct or mandate additional expertise to identify the projects that do not transfer enough rent to the principal. Also, this situation increases the risk of strategic behaviours, due to the limited information provided by the submitted projects.

Step 7: Strengthening of impact assessment and mitigation measures. (Remaining agents and independent experts, with the inclusion of identified stakeholders) 
The applicants of the remaining projects need to provide with a more comprehensive study of the impact assessment for every single project. Independent experts on impact assessment can support this step. Moreover, the principal may ask for some additional specific mitigation measures. For instance, he may have identified some relevant features included in some projects but absent from other submissions. Therefore, he can ask for those relevant features to be inserted in every project.

As new information can result from the realization of the impact assessment, the agent can adjust the planning of new mitigation and compensation measures for those impacts. It shall not affect the rent assessment, as mitigation and compensation costs can be deducted from the total transferred rent.

The results of the impact assessment might be critically reflected in a stakeholder process that runs in parallel with the entire granting process, and by this means help to improve the projects under consideration.

Step 8: Third selective step-Sustainability assessment of projects. (Principal with inclusion of identified stakeholders)

This step aims to bring information for final selection in step 9. The selected project has to be the one reaching the highest score in the SA compared to all the other projects. We assume that the method is specified in step 3 or by European rules. For instance, the Directive 2014/25/EU suggests the use of Life Cycle Assessment. The information gathered during the whole process shall serve and be used in the SA, for example in impact assessments and early identification of stakeholders.

The engagement of stakeholders since the beginning of the process makes sense for this step. First, they can identify critical aspects, but also support the definition of and comprehensiveness of selected sets of criteria and indicators, through an iteration process. Indeed, the choice of criteria and indicators is often entirely done by analysts, and can omit essential matters in one specific situation [66]. Second, they can weigh the criteria and indicators. This weighting process enables on the one hand to identify both consensual and conflictual aspects that exist between stakeholders. On the other hand, it helps to determine which criteria are of a critical or marginal importance for the project selection procedure. In that matter, an important aspect is the number of criteria and indicators considered in the process. A balance between comprehensiveness and comprehensibility of the interest at stake has to be found. However, the "keep it simple" rule advocate for a limited number of indicators to hold and increase the process efficiency. Third and finally, the early integration of stakeholders gives the opportunity to implement a direct interaction between the latter and the agents. It would facilitate the emergence of tailor-made projects to the specific context, once critical aspects have been identified. In that sense, proposed flexible projects would ease this agent-stakeholder interaction and its awaited outcomes, as the margin for flexibility from the agent's side would already be determined.

Step 9: Final step-Decision-making and end of the process. (Principal)

In the light of the outcome provided during the SA of submitted projects (ended in step 8), the principal can provide an informed final decision, and is able to support this final choice in regards with the various stakeholders' perspectives. Indeed, the selected project has to be in complete coherency with the outcome of the SA process and the related stakeholder integration process. This coherency is required for two main reasons. First, it aims to ensure the legitimacy and credibility of the principal, and not discredit the relevancy of the SA process. Second, it aims to actually avoid or decrease future opposition or court action by groups of interests, as their stakes are expected to have been included in the project. The transparency of the decision process is therefore a prime requirement. To make clear and publicly available the way and extend to which stakeholders perspectives on the project have been taken into account is extremely important. It gives the opportunity for stakeholders and more generally, for the public, to witness the decision process. This is expected to increase their understanding about how miscellaneous perspectives have been taken into account and increases per se the legitimacy of the SA and related procedure as a whole. 


\section{Discussion}

The suggested process does not discard difficulties linked to its practical application. Nevertheless, as discussed below, such difficulties are inherent to the complexity of the issue rather than to our proposal. For instance and as exposed previously, SA has some inherent issues, such as a lack of unified method, both regarding approaches and data or resources required (e.g., stakeholder integration, weighted assessment, etc.), which may lead to different perspectives and results.

More specifically, SA of hydropower has its own specificities. Power plants imply long-lasting, large infrastructure and high investments [67]. Widely considered as a renewable energy source [21], hydropower also results in significant impacts on a large range of aspects [68]. On the other hand, storage and pumped-storage hydropower plants are able to provide highly valuable services, for instance flexible electricity generation and ancillary services [67], flood control and water supply [69]. Altogether, those technological specificities make essential the conduction of a SA for any new or retrofitted hydropower project.

Rent assessment is doubtlessly challenging. Inherent issues are uncertainty and lack of transparency. For those matters, profit-based taxes could fix part of the issue. It postpones the assessment to the operating phase. As an ex-post computation, the electricity price is known and not projected. Still, this does not ensure full transparency. If the principal knows the prices, it could still be hard for him to know the actual profit. Indeed, as electricity companies own various power plants, they do not necessarily communicate the profit realized by a specific one. Control and verification could induce large costs. However, this paper does not discuss the pros and cons of each extraction rent system. We argue that our process can be applied to any of them.

In the context of high competition, the uncertainty issue is less alarming. First, it limits the possibility of strategic behaviours. The principal can benefit from the shared information by every agent. The asymmetry of information is therefore mitigated. Second, as detailed in step 6, the principal just has to select the best offers. As competition dynamics apply, the winner agent for each design values the rent at its fair level, at least in theory.

Finally, the process and the final decision are expected to be transparent, as explained in step 9, essential to reduce the risk of public objection. However, the process itself cannot guarantee the absence of any form of opposition to the final decision. As it is out of the scope of this article to address the concerns of a conflict resolution in that matter, we believe that the key aspect here lies in the stakeholder selection process and diversity of integrated stakes. We suggested the realisation of a snowball sampling process, which aims notably to include none-institutional stakeholders that could have been overlooked otherwise. Of course, this process itself and the way it is conducted will have implications on the outcome. Therefore, we can only encourage to include as many stakes as possible to reduce the appearance of opposition to the project.

It is fundamental to be aware of those issues, when regarding the process. However, one shall notice that they are not linked to the process itself. The complexity of the challenges raised indicates the existence of room for further research. Accordingly, this paper provides an innovative insight and method for water rights attribution, but does not address challenges ensuing from the methods used or suggested.

\section{Conclusions}

By inducing distortions in the integrated European market, the granting of water rights for hydropower exploitation constitutes a severe issue for European countries, and not just for those with hydropower capacities. This is the result of the coexistence of two dynamics. On the one hand, the interdependent and integrated European electricity markets follow the same set of rules. On the other hand, the actors in the energy sector face a diversity of national and regional specific procedures and legislation. It especially concerns the attribution process of water rights, as it has been created at the time of the national and local monopolies. It is this coexistence that creates some of the challenges for the current hydropower sector as it affects its crucial need to access water rights. 
The Directive 2014/25/EU indirectly recognizes this issue and requires a competitive process to select energy projects and the integration of sustainable development goals in the decision process. With this article, we build a bridge between this European Directive and the attribution of water rights for hydropower production. We propose a generic framework for granting water rights that consists of nine steps, as illustrated in Figure 1.

The three major goals of this process are: (1) to avoid discrimination in the access to water resources; (2) to prioritize projects that the best comply with the goals of sustainable development; and (3) to ensure efficiency of the process itself. Altogether, this enables a non-discriminatory and harmonized access to the water rights market, and thus prevents from distortions to the electricity market caused by specific local or national barriers to entry. In addition, it integrates legal constraints and financial goals with other societal concerns in the economic, social and environmental realms, which are taken into consideration at different stages of the proposed process.

One strength of this proposal is the encouragement to submit and compare alternative project options, thus creating flexibility in the decision and planning of projects. It can enhance competition even if there are few agents, while the principal gathers a maximum of information, which facilitates the comparison of projects. Furthermore, it boosts the implementation of mitigation and compensation measures as well as the inclusion of sustainable development goals at an early stage of the process, although the effective sustainability assessment must be completed at the penultimate step. Hence, the costliest steps, in terms of time, financial and human resources, are kept to the end, which increases the efficiency of the process. Nonetheless, to increase the rate of success of the whole process and the social acceptance of the selected project, stakeholder identification and involvement must start at the very beginning of the process. Indeed, stakeholders must be involved in the identification and specification of fundamental constraints and later on in the sustainability assessment, which each project must fulfil and pass, respectively.

The main policy implication of our proposal builds on the specific context of the European Union. Harmonization of national hydropower regimes is not mandatory for the European member jurisdictions. However, those countries, along with non-member countries, actively interact on the same electricity trading platforms. As an actual harmonization of legal requirements would be very challenging, the harmonization of the attribution process of water rights appears straightforward and can already benefit from the framework of the Directive 2014/25/EU. However, while the Directive is rather general, our frame specifically addresses hydropower-related issues. It aims at providing a common ground for the hydropower actors through Europe, by providing a framework that suits with legal requirements of each jurisdiction. This approach enables to avoid distortions by a much simpler manner than an international harmonization of rights at the European level.

Some aspects of hydropower make it a very specific issue. One of them is undoubtedly the strong path dependency of granted rights. As exposed above, the duration of the water rights can be extremely long, reaching up to 90 years in some jurisdiction, or can even be unlimited, such as in Sweden or some cases in Great Britain. The presented process allows to reach a balance in the long term, while avoiding any occurrence of abrupt change in European legislation. If happening, such a change could affect the current hydropower operators still linked to the former regime. With this process, we enable new comers to consider change without strong and sudden legal alterations.

Moreover, we believe that the efficiency of the process and the inclusion of multiple stakes make it appealing for the concerned actors. Indeed, it allows to decrease the risk of the emergence of a strong opposition to the selected project, which could result in an abandon. Both principals and agents should be aware of a strong opposition against any project in the selected area, which is provided by the fundamental limits in step 2. Besides, stakeholders, including opposing groups, can benefit from the process to find compromises or consensual positions, allowing the project to be adapted to their needs and requirements. 
Finally, such an approach can contribute to solve a problem that is most of the time overlooked, despite the role played by hydropower in the European electricity supply. It should at least feed the discussion initiated by Glachant et al. [14], arguing for a stronger coordination of national regimes. At stake, there is an important aspect of the European market integration. Now, the whole procedure should be applied and tested in a real case in order to assess its possible implementation.

Author Contributions: The four authors built together the conceptualization of the present research. G.V. and L.G. investigated the research and established the methodology. They drafted the first version of the article. G.V. was in charge of the visualization. F.R. and W.H. were responsible for the funding of this research, along with administration tasks and supervision. They reviewed and edited the draft version of this article.

Acknowledgments: This research has been founded by the National Research Program "Energy Turnaround" (NRP 70) of the Swiss National Science Foundation (SNSF). Further information on the National Research Program can be found at www.nrp70.ch.

Conflicts of Interest: The authors declare no conflict of interests.

\section{References}

1. International Energy Agency (IEA). Key World Energy Statistics; IEA Publications: Paris, France, 2017; ISBN 978-92-64-28321-3.

2. World Energy Council (WEC). Hydropower Resources in Europe. Available online: https://www. worldenergy.org/data/resources/region/europe/hydropower/ (accessed on 18 April 2018).

3. Bundesamt für Energie (BFE). Schweizerische Elektrizitätsstatistik 2016. Available online: https:/ /www. bundespublikationen.admin.ch/cshop_mimes_bbl/8C/8CDCD4590EE41ED797FF3D9EAD3B79B3.pdf (accessed on 5 June 2018).

4. Directorate-General for Energy (European Commission). Roadmap 2050; EU Publications: Luxembourg, 2012.

5. Jamasb, T.; Pollitt, M. Electricity Market Reform in the European Union: Review of Progress towards Liberalisation and Integration; International Association for Energy Economics: Cambridge, MA, USA, 2005; ISBN 9788578110796.

6. Joskow, P.L. Lessons Learned from Electricity Market Liberalization. Energy J. 2008, 29, 9-42. [CrossRef]

7. Batlle, C.; Ocana, C. Electricity Regulation: Principles and Institutions. In Regulation of the Power Sector; Pérez-Arriaga, I.J., Ed.; Springer: London, UK, 2013; ISBN 978-1-4471-5033-6.

8. European Network of Transmission System Operator (ENTSO-E). Annual Report 2015-Electricity without Borders. Available online: https://docstore.entsoe.eu/Documents/Publications/ENTSOEgeneralpublications/ENTSO-E_AR15_FINAL.pdf (accessed on 2 February 2018).

9. Ranci, P.; Cervigni, G. The Economics of Electricity Markets; Edward Elgar Publishing: Cheltenham, UK, 2013; ISBN 9780857933966.

10. Glachant, J.-M.; Saguan, M.; Rious, V.; Gentzoglanis, E. Regimes for Granting Rights to Use Hydropower in Europe; Florence School of Regulation: Florence, Italy, 2014; ISBN 978-92-9084-222-4.

11. Boelens, R.A. The Shotgun Marriage: Water Security, Cultural Politics, and Forced Engagements between Official and Local Rights Frameworks. In Water Security: Principles, Perspectives and Practices; Lankford, B., Bakker, K., Zeitoun, M., Conway, D., Eds.; Routledge: NewYork, NY, USA, 2013; Volume 521, pp. $239-255$. ISBN 9780415534703.

12. United Nations Environment Programme (UNEP). Dams and Development_Relevant Practices for Improved Decision Making, a Compendium of Relevant Practices for Improved Decision-Making on Dams and Their Alternatives; UNEP: Nairobi, Kenya, 2007; ISBN 9789280728163.

13. Pineau, P.O.; Tranchecoste, L.; Vega-Cárdenas, Y. Hydropower royalties: A comparative analysis of major producing countries (China, Brazil, Canada and the United States). Water 2017, 9, 287. [CrossRef]

14. Glachant, J.; Rious, V.; Saguan, M.; Douguet, S. For a Harmonisation of Hydropower Regimes in European Single Market; European University Institute: Florence, Italy, 2016; ISBN 9789290843733.

15. Ricardo, D. On the Principles of Political Economy and Taxation; Cambridge University Press: London, UK, 1817; ISBN 9781108075435.

16. Rothman, M. Measuring and Apportioning Rents from Hydroelectric Power Development; World Bank Discussion Paper No. 419; World Bank: Washington, DC, USA, 2000; pp. 1-49. 
17. Laffont, J.-J.; Martimort, D. The Theory of Incentives: The Principal-Agent Model; Princeton University Press: Princeton, NJ, USA, 2002; ISBN 9780691091846.

18. Amundsen, E.S.; Andersen, C.; Sannarnes, J.G. Rent Taxes on Norwegian Hydropower Generation. Energy J. 1992, 13, 97-116. [CrossRef]

19. Grafton, R.Q. Rent capture in a rights-based fishery. J. Environ. Econ. Manag. 1995, 28, 48-67. [CrossRef]

20. Zhang, L. Neutrality and Efficiency of Petroleum Revenue Tax: A Theoretical Assessment. Econ. J. 1997, 107, 1106-1120. [CrossRef]

21. Frey, G.W.; Linke, D.M. Hydropower as a renewable and sustainable energy resource meeting global energy challenges in a reasonable way. Energy Policy 2002, 30, 1261-1265. [CrossRef]

22. Rametsteiner, E.; Pülzl, H.; Alkan-Olsson, J.; Frederiksen, P. Sustainability indicator development-science or political negotiation? Ecol. Indic. 2009, 11,61-70. [CrossRef]

23. World Commission on Environment and Development (WCED). Our Common Future; Oxford University Press: Oxford, UK, 1987; Volume 4, ISBN 019282080X.

24. Barbier, E. The Concept of Sustainable Economic Development. Environ. Conserv. 1987, 14, 101-110. [CrossRef]

25. Hediger, W. Sustainable development and social welfare. Ecol. Econ. 2000, 32, 481-492. [CrossRef]

26. Gibson, R.B. Sustainability assessment: Basic components of a practical approach. Impact Assess. Proj. Apprais. 2006, 24, 170-182. [CrossRef]

27. World Business Council For Sustainable Development (WBCSD). Corporate Social Responsibility-The WBCSD's Journey. Available online: https://www.globalhand.org/system/assets/ f65fb8b06bddcf2f2e5fef11ea7171049f223d85/original/Corporate_Social_Responsability_WBCSD_2002.pdf (accessed on 19 April 2018).

28. United Nations Sustainable Development Knowledge Platform. Available online: https:// sustainabledevelopment.un.org/topics/nationalsustainabledevelopmentstrategies (accessed on 4 January 2017).

29. Bond, A.; Morrison-Saunders, A.; Pope, J. Sustainability assessment: the state of the art. Impact Assess. Proj. Apprais. 2012, 30, 53-62. [CrossRef]

30. Taisch, M.; Sadr, V.; May, G.; Stahl, B. Sustainability Assessment Tools—State of Research and Gap Analysis; Prabhu, V., Taisch, M., Kiritsis, D., Eds.; Springer: Heidelberg, Germany, 2013; Volume 415, pp. 426-434.

31. Ness, B.; Urbel-Piirsalu, E.; Anderberg, S.; Olsson, L. Categorising tools for sustainability assessment. Ecol. Econ. 2007, 60, 498-508. [CrossRef]

32. Kates, R.W.; Clark, W.C.; Corell, R.; Hall, J.M.; Jaeger, C.C.; Lowe, I.; McCarthy, J.J.; Schellnhuber, H.J.; Bolin, B.; Dickson, N.M.; et al. Environment and development. Sustainability Science. Science 2001, 292, 641-642. [CrossRef] [PubMed]

33. Lior, N. Sustainable energy development: The present (2009) situation and possible paths to the future. Energy 2010, 35, 3976-3994. [CrossRef]

34. International Energy Agency (IEA). Technology Roadmap-Hydropower; IEA Publications: Paris, France, 2012; ISBN 9789264088177.

35. Fearnside, P.M. Impacts of Brazil's Madeira River Dams: Unlearned lessons for hydroelectric development in Amazonia. Environ. Sci. Policy 2014, 38, 164-172. [CrossRef]

36. Skalak, K.J.; Benthem, A.J.; Schenk, E.R.; Hupp, C.R.; Galloway, J.M.; Nustad, R.A.; Wiche, G.J. Large dams and alluvial rivers in the Anthropocene: The impacts of the Garrison and Oahe Dams on the Upper Missouri River. Anthropocene 2013, 2, 51-64. [CrossRef]

37. Lerer, L.; Scudder, T. Health impacts of large dams. Environ. Impact Assess. Rev. 1999, 19, 113-123. [CrossRef]

38. Ma, J.; Liu, Y.; Wang, H.; Yan, D.H.; Lv, Y.K.; Yang, Z. Socioeconomic impacts of hydropower development on the Yibin-Chongqing section, upper reaches of the Yangtze River. Phys. Chem. Earth Parts ABC 2015, 89-90, 73-78. [CrossRef]

39. Fearnside, P.M. Environmental and Social Impacts of Hydroelectric Dams in Brazilian Amazonia: Implications for the Aluminum Industry. World Dev. 2016, 77, 48-65. [CrossRef]

40. Tilt, B.; Braun, Y.; He, D. Social impacts of large dam projects: A comparison of international case studies and implications for best practice. J. Environ. Manag. 2009, 90, S249-S257. [CrossRef] [PubMed]

41. Ansar, A.; Flyvbjerg, B.; Budzier, A.; Lunn, D. Should we build more large dams? The actual costs of hydropower megaproject development. Energy Policy 2014, 69, 43-56. [CrossRef] 
42. Demsetz, H. Why Regulate Utilities? J. Law Econ. 1968, 11, 55. [CrossRef]

43. Goldberg, V.P. Competitive Bidding and the Production of Precontract Information. Bell J. Econ. 1977, 8, 250-261. [CrossRef]

44. Williamson, O.E. Franchise Bidding for Natural Monopolies-in General and with Respect to CATV. Bell J. Econ. 1976, 7, 73-104. [CrossRef]

45. Porter, M.E. How Competitive Forces Shape Strategy. Harv. Bus. Rev. 1979, 57, 137-145. [CrossRef]

46. Laffont, J.-J.; Tirole, J. A Theory of Incentives in Procurement and Regulation; The MIT Press: Cambridge, UK, 1993; Volume 1, ISBN 9780262121743.

47. Joskow, P.L.; Schmalensee, R. Incentive Regulation for Public Utilities. Yale J. Regul. 1986, 4, 1-49. [CrossRef]

48. Owen, B.M.; Braeutigam, R. The Regulation Game: Strategic Use of the Administrative Process; Ballinger Press: Cambridge, UK, 1978; ISBN 0884100669.

49. Williamson, O.E. Markets and Hierarchies: Analysis and Antitrust Implications: A Study in the Economics of Internal Organization; Free Press: New York, NY, USA, 1975; ISBN 0029353602.

50. Hart, O.; Moore, J. Property Rights and the Nature of the Firm. J. Polit. Econ. 1990, 98, 1119-1158. [CrossRef]

51. Grossman, S.; Hart, O. The Costs and Benefits of Ownership: A Theory of Vertical and Lateral Integration. J. Polit. Econ. 1986, 94, 691-719. [CrossRef]

52. Kasimir, B.; Jaeger, C.C.; Jäger, J. Public Participation in Sustainability Science; Cambridge University Press: Cambridge, UK, 2003; ISBN 9780511490972.

53. Toman, M.A.; Lile, R.; King, D. Assessing Sustainability: Some Conceptual and Empirical Challenges; Resources for the Future: Washington, DC, USA, 1998.

54. Freeman, R.E.; Harrison, J.S.; Wicks, A.C.; Parmar, B.; de Colle, S. Stakeholder Theory: The State of the Art; Cambridge University Press: Cambridge, UK, 2010; Volume 53, ISBN 9788578110796.

55. Shortall, R.; Davidsdottir, B.; Axelsson, G.A. Development of a sustainability assessment framework for geothermal energy projects. Energy Sustain. Dev. 2015, 27, 28-45. [CrossRef]

56. Rosso, M.; Bottero, M.; Pomarico, S.; La Ferlita, S.; Comino, E. Integrating multicriteria evaluation and stakeholders analysis for assessing hydropower projects. Energy Policy 2014, 67, 870-881. [CrossRef]

57. Shortall, R.; Davidsdottir, B.; Axelsson, G. A sustainability assessment framework for geothermal energy projects: Development in Iceland, New Zealand and Kenya. Renew. Sustain. Energy Rev. 2015, 50, 372-407. [CrossRef]

58. Leventon, J.; Fleskens, L.; Claringbould, H.; Schwilch, G. An applied methodology for stakeholder identification in transdisciplinary research. Sustain. Sci. 2016, 11, 763-775. [CrossRef]

59. Atkinson, R.; Flint, J. Accessing Hidden and Hard-to-Reach Populations: Snowball Research Strategies. Soc. Res. Updat. 2001, 33, 1-4. Available online: http://sru.soc.surrey.ac.uk/SRU33.html (accessed on 2 February 2018).

60. Siciliano, G.; Urban, F.; Kim, S.; Dara, P. Hydropower, social priorities and the rural-urban development divide: The case of large dams in Cambodia. Energy Policy 2015, 86, 273-285. [CrossRef]

61. Siciliano, G.; Urban, F.; Tan-Mullins, M.; Mohan, G. Large dams, energy justice and the divergence between international, national and local developmental needs and priorities in the global South. Energy Res. Soc. Sci. 2018, 41, 199-209. [CrossRef]

62. Souza, R.G.; Rosenhead, J.; Salhofer, S.P.; Valle, R.A.B.; Lins, M.P.E. Definition of sustainability impact categories based on stakeholder perspectives. J. Clean. Prod. 2015, 105, 41-51. [CrossRef]

63. Hediger, W.; Voegeli, G. Sustainability Assessment of Swiss Hydropower, A Note on the State of the Art and Prospects for an Integrated Approach; Background Paper Prepared for Arbeitsgruppe Energieforschung, Alpen, Bern, 9.-10.06.2016; Mountain Workshop: Danbury, CT, USA, 2016.

64. Künkel, P.; Gerlach, S.; Frieg, V. Stakeholder-Dialoge Erfolgreich Gestalten: Kernkompetenzen für Erfolgreiche Konsultations-und Kooperationsprozesse; Springer Gabler: Wiesbaden, Germany, 2016; ISBN 3658105690.

65. Baur, P.; Hediger, W. Wasserkraft, Energiewende und nachhaltige Entwicklung: Vielfältige Auswirkungen, schmerzhafte Abwägungen. Wissensplatz 2016, 2, 22-23.

66. Gasparatos, A. Embedded value systems in sustainability assessment tools and their implications. J. Environ. Manag. 2010, 91, 1613-1622. [CrossRef] [PubMed]

67. Gaudard, L.; Romerio, F. The future of hydropower in Europe: Interconnecting climate, markets and policies. Environ. Sci. Policy 2014, 37, 172-181. [CrossRef] 
68. Kaunda, C.S.; Kimambo, C.Z.; Nielsen, T.K. Hydropower in the Context of Sustainable Energy Supply: A Review of Technologies and Challenges. ISRN Renew. Energy 2012, 2012, 730631. [CrossRef]

69. World Commission on Dams (WCD). Dams and Development: A New Framework for Decision-Making; Earthscan Publications Ltd.: Oakland, CA, USA, 2000; ISBN 1-85383-798-9. 